\title{
The Impact of COVID-19 on the Financial Performance of Bank Dhofar
}

Adnan Ali Al-Bimani ${ }^{1}$, Maria Teresa Matriano ${ }^{2}$

Middle East College, Oman

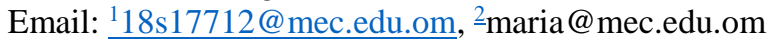

Citation: AL-Bimani, A. A. \& Matriano, M. T. (2021). The Impact of COVID-19 on the Financial Performance of Bank Dhofar. International Journal of Research in Entrepreneurship \& Business Studies, 2(3), 47- 46.

https://doi.org/10.47259/ijrebs.235

Received on $28^{\text {th }}$ Apr. 2021

Revised on $25^{\text {th }}$ May. 2021

Published on $30^{\text {th }}$ Jun. 2021

Copyright: (C) 2021 by the authors. Licensee Global Scientific Publications, Oman.

\section{Publishers Note:}

This work is licensed under a Creative Commons Attribution-ShareAlike 4.0 International License. This is an openaccess journal and the articles published in this journal are distributed under the terms of CC-BY-SA.

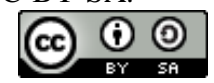

\begin{abstract}
Purpose: The aims of this research were to identify how COVID-19 had affected the financial performance of Bank Dhofar, to analyze the financial performance indicators, to evaluate how did Bank Dhofar react to the changes, and to evaluate whether Bank Dhofar had taken the right action take to mitigate potential financial performance damages.
\end{abstract}

Design/methodology/approach: This research follows a descriptive analytics research method. The primary data was collected using a questionnaire. Samples were selected based on a random sampling technique. 30 samples were collected from those who were related to and involved in the audit and accounting of the financial information services of Bank Dhofar. Once the data was collected, the analysis was done using Microsoft Excel.

Findings: Based on the financial reports, COVID-19 has negatively impacted the profit generated of Bank Dhofar and also negatively impacted the Net Interest Margin (NIM). Bank Dhofar had also taken necessary precautionary measures against COVID-19 such as reserves and provisions.

Research limitations/implications: Based on the results, it was recommended that the Bank focuses on the digitized platform for an even more efficient means of working remotely and focus on employee morale, as these factors may negatively impact financial performance.

Social Implications: This research would add collective knowledge on how COVID-19 affected the nation and could influence decision-makers, rules, and regulations.

Originality / Value: No research was found regarding the financial performance of a bank in Oman during COVID-19. This research was an attempt to tackle the situation and thrown light.

Keywords: Financial Performance, Bank Dhofar, Financial Performance of the Bank, Banking Sector, COVID-19.

\section{Introduction}

COVID-19, also referred to as the novel Corona Virus has caused a pandemic of global proportions, affecting the entire world. It has started its spread in November 2019 remains an active threat globally and its effect was noticed in almost all the countries disturbing all the functions like business, tourism, health care, Banking, etc. Its effect has been documented by the World Health Organization (WHO, 2020). Due to the rapid spread of the disease and how powerful it was, all countries had to change the way, they function and adapt to reduce the damage it had caused. Despite the major damage that had already been done worldwide including the banking sector (Chriscaden, 2020).

Bank Dhofar started in 1990 operates in the Sultanate of Oman, which has branches spread over the nation. The bank and since then, have remained to deliver banking products and services to its customers. Initially, it was called Bank Dhofar al Omani Al Fransi merging with Majan International Bank during the year 2003 was renamed as Bank Dhofar. It is considered as the most successful bank in Oman by Forbes and Best Islamic Bank of the year 2020, the best investment bank of the year 2020 (Bank Dhofar, 2021). Further, the bank was considered to be the second-largest bank in possessing assets and asset growth (Khan and Al Maktoumi, 2021). At the end of the year 2020, there were only sixty-seven active branches, ten of which were specialized in Islamic banking products and services. 
Small and medium-sized enterprises were got affected due to the lockdowns of COVID-19 and the businesses got slowed down which in turn affected the economy (Mustapa and Mohamed, 2021). COVID-19 has also impacted the banking sector globally. In the GCC region, because of COVID-19, the dividends were 'slashed' and it was stated that the dividends went down from $\$ 14.6$ billion to $\$ 8.0$ billion from 2019 to 2020 respectively (Times of Oman, 2021). The stock volatility has increased slightly and that there is a confirmed presence of volatility (Insaidoo et al., 2021). In Istanbul, COVID-19 affected the banking sector negatively, as it had suffered a decline in economic activities (Karaömer and Kakilli Acaravc1, 2021). In India, during the lockdown period, banks struggled with losses from their non-performing assets and have caused a decline in the credit growth of banks especially in public sector banks (Singh and Bodla, 2020). Testing the resilience of banks, it was found that different banks had different resilience (Ghosh and Samia, 2021).

Through financial performances, the health of an organization in terms of finances can be identified. There are various methods to calculate financial performance. COVID-19 has impacted the economical and budgetary landscapes and by using certain economic indicators, the impact could be understood on the effects on the economy (Jose et al., 2021). In this study financial indicators were used to identify the financial performances of the bank. The financial indicators used were Profits, Operating Income, and net interest margin (NIM).

\section{Research Questions}

1. How had COVID-19 affected the financial performance of Bank Dhofar?

2. What were the financial performance indicators that will measure the financial performance during COVID-19?

3. How had Bank Dhofar adapted during the period of COVID-19?

4. Has Bank Dhofar taken the right procedures during the period of COVID-19 in regards to financial performance?

\section{Research Objectives}

1. To identify how had COVID-19 affected the financial performance of Bank Dhofar.

2. To identify and analyze financial performance indicators during COVID-19.

3. To evaluate how Bank Dhofar adapted to the changes that came with COVID-19.

4. To evaluate whether Bank Dhofar had taken the right action take to mitigate potential financial performance damages.

\section{Statement of the Problem}

COVID-19 has affected all types of activities either to halt or to alter the way they operate. The Sultanate of Oman, along with many other countries, had to enact rules and regulations in curbing the spread of the disease by reducing the workforce by $50 \%$ in the place of work and reducing working hours in some sectors. It has also introduced partial lockdowns within and between provinces and temporarily shut down other activities.

This has created more and more difficulties for businesses to survive and bring down the financial position and the performances of the companies including banks. Bank Dhofar also got affected by COVID-19. It is becoming essential to identify whether the preventive measures and the changes introduced to curb COVID19 and the regulations had an impact on the financial performance of Bank Dhofar, and to what extent the impact was. It is also becoming necessary to find out whether Bank Dhofar adapted to the situation and What actions were taken to cope up with the situation and in preventing financial losses if any. Further, it is also becoming important to know the mindset of employees and therefore the study was undertaken.

\section{Review of Literature \\ Impact of COVID-19}

COVID-19 had a strong negative impact on the stock indices (Al-Najjar et al., 2021). Some sectors have a strong impact and different impacts based on their size and the market (Golubeva, 2021). COVID-19 has caused huge damage around the world and every organization is to minimize the damage (Mukherjea, 2010). One of the major impacts of the pandemic was the loss of jobs by many due to certain businesses shutting down, and an increase in energy and resource consumption causing loss or reduction of income (Abdulai \& Baffour, 2021). Banks in Germany had a variety of solutions and repercussions to reduce the damage that was caused due to the pandemic (Flögel and Gärtner, 2020). It was claimed that small firms were the most vulnerable to the shock and the damages as technology-aided is highly required in the recovery phases of said organizations (Čadil et al., 2021). Even some of the banking employees were laid-off and were not able 
to repay their loans, which caused the profits to decrease (Beck et al., 2020). Banks introduced new sanitary procedures in relates to hygiene before entering the branches which caused dissatisfaction among the customers and the employees (Alharthi et al., 2021). Government acting through public financial management in such situations by making proper decisions that aid or increase the financial performance of a country (Ball, 2020).

\section{Measures to Overcome}

To overcome the impacts of the pandemic, it was recommended to invest in a digitalized platform for business activities that will aid in the growth of the digital economy (Ozili, 2020). COVID-19 has forced almost all the companies and organizations in the country to move towards a digitized process for performing their transactions thereby investing themselves towards creating a digitized environment (Rehman et al., 2021). Governments, banks, and firms also started investing in digital programs, artificial intelligence, and online securities as the shift towards a digitized working environment become smoother (Albitar et al., 2021). It is expected during these times of uncertainty, organizations need to be transparent with their financial health recording and reporting their financials ( $\underline{\mathrm{Og} u z}, 2021)$. During this period of uncertainty, some of the banks have adopted sweeping action and some others with 'wait and see' action to gauge the reaction during the uncertain situation as a proactive measure compared to other sectors (Talbot and Ordonez, 2020). Despite the negative impact COVID-19 had on the returns on stock, the lockdown had a positive impact on the stock performance of the stock markets and the financial sector was the sector that got highly affected negatively (Anh and Gan, 2021)

\section{Efforts of the Banks}

Commercial banks were able to predict certain government policies towards encouragement towards the shift towards digital adoption (Mansour, 2021). The performance expectancy of internet banking, the effort expectancy, and price range had influenced the willingness of adapting internet banking into the bank's system (Thaker et al., 2021). The factors aid in the success of E-banking was the proper management of operations and the innovation of operations. These two factors were very crucial in the success of Electronic Banking (Hway-Noon and Ming Yu, 2013). Further, the quality, service, privacy, and security factors were crucial towards the attitude of moving towards internet banking. (Ofori et al., 2017). During the pandemic, loyalty towards E-Banking has increased and customers felt it was safer for themselves both to perform banking transactions using the electronic channels provided by the banks (U1 Haq and Awan, 2020).

The usage of mobile banking was influenced by several factors such as the present COVID-19 situation and the dire need to adhere to social distancing, and therefore the policies and regulations regarding mobile payment with the context of social distancing were developed and maintained (Sreelakshmi and Prathap, 2020). As there is no high risk reported to be involved in using a mobile banking platform and the younger generation prefers to do banking through mobile platform mobile banking is becoming popular (Priya et al., 2018). The trend of mobile banking and online banking has brought in the fold of banks the unbanked customers in developing markets (Anderson, 2010). The success of mobile banking is due to the five components viz. attributes, customer-based, social influence, trust, and barriers (Souiden et al., 2021).

Considering the growth in the digital market banking sector should utilize its growth to benefit themselves and the nation, keeping in mind protecting public interests (Tsindeliani et al., 2021). Banks and nations should utilize Digital Financial Inclusion (DFI) to maintain banking stability to reduce the crisis of liquidity (Banna and Alam, 2021). Further, technological readiness has a significant positive impact on client satisfaction in terms of self-service (Pooya et al., 2020). The introduction of compassionate policies might help to prevent stress, absenteeism, decrease productivity and encourage the morale of the employees (Oruh et al., 2021). In Ghana, though thousands of employees were laid off and various sectors lost huge amounts, the country turned this into employment opportunities by investing in the health sector and provided support to small and medium enterprises thereby increasing the morale of the community (Aduhene and OseiAssibey, 2021).

\section{Research Methodology}

This research follows a descriptive analytics research method. The primary data was collected using a questionnaire. Samples were selected based on a random sampling technique. 30 samples were collected from those who were related to and involved in the audit and accounting of the financial information services of Bank Dhofar. The data was collected starting from April to June. The data was collected using an online tool. Once the data was collected, the analysis was done using Microsoft Excel. 
The data were evaluated using this application. The following calculations were done as follows:

Calculation 1: Percentage decrease in profit was calculated using the difference in profit figures divided by the previous year's profit figure. i.e. Percentage in Decrease $=$ Difference $\div$ Profit (previous year) $\mathrm{x} 100$

Calculation 2: Net Interest Margin (NIM) was calculated using the formula Difference between the interest earned and interest paid divided by the average assets invested.

i.e. Net Interest Margin $=($ Interest Income - Interest Paid $) \div$ Average Assets Invested where

Average Invested Assets $=($ Total Assets of Current Year - Total Assets of Previous Year $) \div$ Number of Years

\section{Findings}

Profit

Table 1 Profit of Bank Dhofar

\begin{tabular}{|l|c|c|c|c|c|c|}
\hline Year & 2015 & 2016 & 2017 & 2018 & 2019 & 2020 \\
\hline Profit & 47 & 48 & 48 & 50 & 30 & 30 \\
\hline
\end{tabular}

The profit has seen a significant drop between the years 2018 and 2019. The recorded percentage decrease in profit was 39\%. Between 2019 and 2020, there was no notable change in profits. The year 2020 had COVID-19's effect in full force.

\section{Operating Income}

Table 2 Operating Income

\begin{tabular}{|l|c|c|c|c|c|c|}
\hline Year & 2015 & 2016 & 2017 & 2018 & 2019 & 2020 \\
\hline $\begin{array}{l}\text { Operating } \\
\text { Income }\end{array}$ & 115 & 127 & 127 & 134 & 130 & 130 \\
\hline
\end{tabular}

There was a major increase in operating profits of Bank Dhofar from 2015 to 2016, then it was stagnant in 2016 and 2017, then it reached its highest in 2018 and then dropped in 2019 and 2020. The decrease in operating income was recorded at $2.2 \%$ only.

\section{Net Interest Margin}

Table 3 Net Interest Margin (NIM)

\begin{tabular}{|c|c|c|c|c|}
\hline Year & $\begin{array}{c}\text { Interest } \\
\text { Income }\end{array}$ & Interest Paid & $\begin{array}{c}\text { Average } \\
\text { Invested Assets }\end{array}$ & NIM \\
\hline 2015 & 118173 & 33695 & 199467 & 0.423519 \\
\hline 2016 & 141536 & 50750 & 179491 & 0.505797 \\
\hline 2017 & 161499 & 76894 & 147333.5 & 0.574241 \\
\hline 2018 & 174766 & 86848 & -16610 & -5.29308 \\
\hline 2019 & 182125 & 85485 & 56177.5 & 1.720262 \\
\hline 2020 & 174944 & 82725 & -34411 & -2.67993 \\
\hline
\end{tabular}

Table 3 indicated that the profitability of Bank Dhofar decreased sharply in the year 2018, rose during the year 2019, then dropped again during the year 2020. This indicated that during the years 2018 and 2020, the investment of the bank decreased by $2 \%$. The general accepted net interest margin (NIM) in US banks was $3 \%$ (Ross, 2019). 
Financial Highlights

Table 4 Income Expenditure Details

\begin{tabular}{|l|c|c|c|c|c|}
\hline Year/Activity & $\mathbf{2 0 2 0}$ & $\mathbf{2 0 1 9}$ & $\mathbf{2 0 1 8}$ & $\mathbf{2 0 1 7}$ & $\mathbf{2 0 1 6}$ \\
\hline Net Interest Income & 92,219 & 84,489 & 87,918 & 84,605 & 90,786 \\
\hline $\begin{array}{l}\text { Net Income from Islamic Financing and } \\
\text { Investment Activities }\end{array}$ & 15,421 & 10,182 & 9,509 & 8,521 & 6,874 \\
\hline Non-Interest Income & 22,353 & 35,133 & 34,426 & 33,801 & 29,691 \\
\hline Operating Costs & 65,079 & 71,474 & 65,456 & 58,994 & 56,767 \\
\hline $\begin{array}{l}\text { Operating Profit (before impairment } \\
\text { losses) }\end{array}$ & 64,914 & 58,490 & 66,397 & 67,933 & 70,584 \\
\hline Profit from Operations & 35,923 & 36,092 & 59,743 & 56,031 & 54,429 \\
\hline Net Profit for the Year & 30,585 & 30,244 & 50,281 & 47,627 & 47,622 \\
\hline
\end{tabular}

Source: Bank Dhofar website

Table 5 Assets Details

\begin{tabular}{|l|c|c|c|c|c|}
\hline \multicolumn{1}{|c|}{ Year/Activity } & $\mathbf{2 0 2 0}$ & $\mathbf{2 0 1 9}$ & $\mathbf{2 0 1 8}$ & $\mathbf{2 0 1 7}$ & $\mathbf{2 0 1 6}$ \\
\hline \multicolumn{1}{|c|}{ Total Assets } & $4,257,023$ & $4,325,845$ & $4,213,490$ & $4,246,710$ & $3,592,043$ \\
\hline $\begin{array}{l}\text { Net Loans, Advances and } \\
\text { Financing }\end{array}$ & $2,911,900$ & $3,063,350$ & $3,158,844$ & $3,248,873$ & $2,988,592$ \\
\hline Customer Deposits & $2,861,315$ & $2,943,188$ & $2,924,504$ & $3,068,409$ & $2,885,189$ \\
\hline Total Equity & 695,864 & 686,155 & 698,162 & 587,007 & 534,000 \\
\hline Share Capital & 299,635 & 299,635 & 280,033 & 225,786 & 189,920 \\
\hline Full-Service Branches & 67 & 71 & 71 & 69 & 68 \\
\hline ATMs/CDMs/FFMs/MFKs & 193 & 194 & 190 & 179 & 180 \\
\hline Staff & 1,522 & 1,586 & 1,600 & 1,514 & 1,478 \\
\hline
\end{tabular}

Source: Bank Dhofar website

Tables 4 and 5 provide the financial highlights of the bank. As seen from the tables, there is a decrease in operations. Comparing operating profit before and after impairment losses. Other than that, there is not a notable change in the financial performance of Bank Dhofar. The number of staff has increased over the years, reaching its peak in 2018, and then continuously dropped in the year 2019 and further in the year 2020. The number of active branches has also decreased, reaching the lowest in 5 years during 2020 with 67 branches. There is a decrease in customer deposits, net loans, and assets compared to the previous years 2019 and 2020.

Demographic Details of the Survey Participants

Table 6 Demography of the respondents

\begin{tabular}{|l|l|c|c|}
\hline Characteristics & \multicolumn{1}{|c|}{ Category } & Freq. & \% \\
\hline \multirow{3}{*}{ Gender } & Male & 21 & 70.0 \\
\cline { 2 - 4 } & Female & 9 & 30.0 \\
\hline \multirow{4}{*}{ Age } & $20-30$ years & 21 & 70.0 \\
\cline { 2 - 4 } & $30-40$ years & 7 & 23.3 \\
\cline { 2 - 4 } & $>40$ years & 2 & 6.7 \\
\hline \multirow{4}{*}{ Department } & Omani & 26 & 86.7 \\
\cline { 2 - 4 } & Non-Omani & 4 & 13.3 \\
\hline & Finance & 14 & 46.7 \\
\cline { 2 - 4 } & Legal & 4 & 13.3 \\
\cline { 2 - 4 } & Customer Service & 9 & 30.0 \\
\cline { 2 - 4 } & Others & 3 & 10.0 \\
\hline
\end{tabular}

Most of the respondents were males and between the ages of $20-30$ and Omani citizens. It is also can be seen that most of the respondents were from the finance department.

Table 7 COVID-19 Effect on Work

\begin{tabular}{|c|c|c|c|c|c|}
\hline Statement & SD & D & N & A & SA \\
\hline \multirow{2}{*}{ COVID-19 has affected your Work } & 1 & 1 & 9 & 10 & 9 \\
& $3.3 \%$ & $3.3 \%$ & $30 \%$ & $33.4 \%$ & $30 \%$ \\
\hline
\end{tabular}


Based on the responses, the majority of respondents $(63.4 \%)$ agreed that COVID-19 has indeed affected their work. $30 \%$ of the respondents neither agreed nor disagreed. Only $6.6 \%$ of the respondents disagreed that COVID-19 has affected their work. Therefore, it was confirmed that COVID-19 had indeed affected the work of the employees of Bank Dhofar.

Table 8 COVID-19 Effect on Work Environment

\begin{tabular}{|l|c|c|c|c|c|}
\hline \multicolumn{1}{|c|}{ Statement } & SD & D & N & A & SA \\
\hline COVID-19 has Affected the & 3 & 0 & 5 & 12 & 10 \\
Work Environment & $10.4 \%$ & $0 \%$ & $16.6 \%$ & $39.6 \%$ & $33.4 \%$ \\
\hline
\end{tabular}

Based on the responses, the overwhelming majority of the respondents (73\%) agreed that COVID-19 has indeed affected their working environment and has indeed shifted during COVID-19, while only $10.4 \%$ disagreed that the working environment has not changed. The remaining $16.6 \%$ were indifferent whether there was a change or not. Therefore, it was assumed that there was a change in the working environment.

Table 9 Preference of Work

\begin{tabular}{|l|c|c|c|c|c|}
\hline \multicolumn{1}{|c|}{ Statement } & SD & D & N & A & SA \\
\hline Working from home is more efficient & 2 & 13 & 8 & 5 & 2 \\
than working at Office & $6.7 \%$ & $43.3 \%$ & $26.7 \%$ & $16.6 \%$ & $6.7 \%$ \\
\hline
\end{tabular}

Based on the responses, the majority of the respondents (50\%) disagreed that working from home is efficient than working at the office and they prefer working in the Bank itself rather than working at home while 26.7 $\%$ of the respondents were indifferent. $23.3 \%$ of the respondents agreed that working from home is efficient than working at the office and they prefer working at home.

Table 10 Impact of Lockdowns Rules and Regulations towards Financial Performance
\begin{tabular}{|l|c|c|c|c|c|}
\hline \multicolumn{1}{|c|}{ Statement } & SD & D & N & A & SA \\
\hline The rules and regulations of COVID- & 2 & 17 & 7 & 3 & 1 \\
$\begin{array}{l}\text { 19 lockdowns have positively } \\
\text { influenced Financial Performance }\end{array}$ & $6.6 \%$ & $56.6 \%$ & $23.1 \%$ & $10.4 \%$ & $3.3 \%$ \\
\hline
\end{tabular}

Based on the responses, the majority of the respondents $(63.2 \%)$ disagreed that the lockdown rules and regulations had a positive influence on financial performance. i.e. Majority of the employees claimed that the rules and regulations of COVID-19 lockdown negatively influenced the financial performance of the bank. Only $13.7 \%$ of the respondents agreed that there was a positive influence of the lockdown rules and regulations on the financial performance and the remaining $23.1 \%$ were neutral. There are some speculations as to why the rules and regulations may have affected the financial performance. It could be because of the rules, certain services, such as maintenance, for example, were slower, which impeded the efficiency of the work causing an indirect impact on the financial performance. It could also because of the reduced workforce from the bank as there was an increase of pressure to do certain functions, without sufficient employees working in the branch, which could have caused a decline in efficiency impacting the financial performance.

Table 11 Opinion towards Precaution

\begin{tabular}{|c|c|c|c|c|c|}
\hline Statement & SD & D & N & A & SA \\
\hline \multirow{2}{*}{ Actions taken were Appropriate } & 1 & 5 & 12 & 10 & 2 \\
& $3.3 \%$ & $16.7 \%$ & $40.0 \%$ & $33.4 \%$ & $6.6 \%$ \\
\hline
\end{tabular}

Based on the responses, the majority are indifferent towards the action taken. $40 \%$ of the respondents agreed that the actions taken were appropriate whereas $40 \%$ of the respondents were neutral towards the changes, and only $20 \%$ of the respondents disagreed. These actions were lockdowns other such actions as stated in Table 11 were preventative actions taken to halt/limit the spreading of COVID-19.

Table 12 Measure of Satisfaction

\begin{tabular}{|l|c|c|c|c|c|}
\hline \multicolumn{1}{|c|}{ Statement } & SD & D & N & A & SA \\
\hline $\begin{array}{l}\text { Employees were satisfied with } \\
\text { the changes }\end{array}$ & 1 & 11 & 4 & 14 & 0 \\
& $3.3 \%$ & $36.7 \%$ & $13.3 \%$ & $46.7 \%$ & $0 \%$ \\
\hline
\end{tabular}


The majority of the respondents $(46.7 \%)$ agreed that the employees were satisfied with the changes and the preventative actions are taken while $40 \%$ disagreed as they were not satisfied with the changes. The remaining $(13.3 \%)$ were neutral. This could have two implications. This could either mean that despite the respondents feeling that the bank had taken proper precautions, the changes left a negative impression towards them; for at least $40 \%$. This could mean that they were not satisfied with the changes and the alterations to the working environment that had occurred. As for the majority (46.7\%) of the respondents, the satisfaction was because despite the changes they were grateful for the actions taken with the change in working environments to combat the spreading of COVID-19.

Table 13 Regression Statistics

\begin{tabular}{|l|r|}
\hline Multiple R & 0.4999 \\
\hline R Square & 0.2499 \\
\hline Adjusted R Square & 0.0543 \\
\hline Standard Error & 1.0679 \\
\hline Observations & 30 \\
\hline
\end{tabular}

Table 14 ANOVA

\begin{tabular}{|l|l|r|c|c|c|}
\hline & df & \multicolumn{1}{|c|}{ SS } & MS & F & Sig. F \\
\cline { 1 - 4 } Regression & 6 & 8.739 & 1.4565 & 1.2773 & .306 \\
\cline { 1 - 4 } Residual & 23 & 26.228 & 1.1403 & & \\
\hline Total & 29 & 34.967 & & & \\
\hline
\end{tabular}

Table 15 Coefficients

\begin{tabular}{|c|c|c|}
\hline & Coefficients & p-value \\
\hline Intercept & 5.572 & .003 \\
\hline Q5 & -0.266 & .341 \\
\hline Q6 & 0.012 & .958 \\
\hline Q7 & -0.546 & .024 \\
\hline Q8 & -0.083 & .712 \\
\hline Q9 & 0.089 & .723 \\
\hline Q10 & -0.445 & .123 \\
\hline
\end{tabular}

Tables 13, 14, and 15 show the results obtained from the regression analysis. The regression analysis was carried out considering question 4 as the dependent variable and questions 5 to 10 as independent variables. Based on the R square value (.2499), it can be inferred that $24.99 \%$ were the samples were influenced by the proposition i.e. the employees of Bank Dhofar work affected (Porterfield, 2017). Though the impact was not that high there was a negligible impact. Also, from the ANOVA analysis (Table 14) and the significance value of $\mathrm{F}$ (.306), as the $\mathrm{p}$-value is $>0.05$ the claim is rejected i.e. it does not have a major impact (Porterfield, 2017).

Further considering the correlation coefficients, it can be claimed as per Porterfield (2017) that if the coefficient values are positive there will be a positive effect, and a negative effect if the value is below 0 . Negative means that there is no correlation and positive means that there is a correlation. Further, the p-value should be less than 0.05 .

Table 16 Interpretation Details

\begin{tabular}{|c|c|l|l|l|}
\hline$\#$ & between & Correlation & \multicolumn{1}{|c|}{ p-value } & \multicolumn{1}{|c|}{ Interpretation } \\
\hline 2 & Q4 \& Q5 & $\begin{array}{l}\text { Less but } \\
\text { positive }\end{array}$ & $\begin{array}{l}>0.05 \\
\text { No impact }\end{array}$ & $\begin{array}{l}\text { Too difficult to ascertain if the departments of } \\
\text { employees affected their work. }\end{array}$ \\
\hline 3 & Q4 \& Q6 & $\begin{array}{l}\text { Less but } \\
\text { positive }\end{array}$ & $\begin{array}{l}>0.05 \\
\text { No impact }\end{array}$ & $\begin{array}{l}\text { Too difficult to ascertain whether the relationship } \\
\text { between the working environment according to the } \\
\text { employees and their departments }\end{array}$ \\
\hline 4 & Q4 \& Q6 & $\begin{array}{l}\text { Medium } \\
\text { positive }\end{array}$ & Close to 0. & $\begin{array}{l}\text { The employees prefer for working from home or } \\
\text { working in the place ultimately depends on the } \\
\text { department they were in. }\end{array}$ \\
\hline 5 & Q4 \& Q8 & $\begin{array}{l}\text { Less but } \\
\text { positive }\end{array}$ & $\begin{array}{l}>0.05 \\
\text { No impact }\end{array}$ & $\begin{array}{l}\text { There is almost no correlation between departments } \\
\text { of the employees and their opinions on the financial } \\
\text { performance. }\end{array}$ \\
\hline
\end{tabular}




\begin{tabular}{|c|l|l|l|l|}
\hline 6 & Q4 \& Q9 & $\begin{array}{l}\text { Less but } \\
\text { positive }\end{array}$ & $\begin{array}{l}>0.05 \\
\text { No impact }\end{array}$ & $\begin{array}{l}\text { There is no correlation between the employees' } \\
\text { working department and their opinions on whether } \\
\text { the proper actions were taken or not. }\end{array}$ \\
\hline 7 & Q4 \& Q10 & $\begin{array}{l}\text { Medium } \\
\text { positive }\end{array}$ & $\begin{array}{l}\text { Close to 0. } \\
\text { Impact }\end{array}$ & $\begin{array}{l}\text { For the most part, the level of satisfaction of } \\
\text { employees depends on the department they are } \\
\text { working in. }\end{array}$ \\
\hline
\end{tabular}

\section{Discussion}

COVID-19 has indeed impacted the financial performance of Bank Dhofar. The net profits of the bank were negatively affected. There was a decrease in profit starting from 2019. This was similar to the finding by Khan \& Al Maktoumi (2021). It was found that the reason for the decline was mostly because of investing in a digitized platform and investing in opening technologically advanced branches. In 2020, the decrease was because of provisions, towards precautionary action against disruption of business activities due to COVID-19.

Operating income remained the same and consistent. It was confirmed that the banking activities such as providing loans remained consistent while business opportunities and investment opportunities were affected. The assets and liabilities were also consistent with previous years with not much of a change. Although assets decreased from 2019 and 2020, so did the liabilities of the bank. In 2018 and 2020, the average interest was negative.

The NIM also decreased in the year 2020, but not much in 2018. The NIM of the Bank was also affected negatively. The bank either gained more assets or had an increase in revenue or had a decrease in liabilities. The operating income of the bank was not affected by COVID-19 which indicated that the operations of the bank were proceeding normally during COVID-19. But, there is a notable difference in the financial performance of the Bank before and during COVID-19.

It was reported that there was a change occurred due to COVID-19. The way work was done in the Bank got changed a lot and the working environment also had changed. This made the employees adapt to the changes, whether they were aptly prepared or not. One of the major changes was that some employees were forced to work from home, a task which many felt not efficient to carry out due to their reasons. This could have caused a perception of decreased financial performance among the respondents. This might be the reason why some employees seemed to be stressed to work. While a lot of the employees stated that the Bank and the Higher Committee have taken the proper steps to combat the interview and questionnaire show that

It was observed that some were satisfied with the change action taken by the Supreme Committee and in turn, the bank to combat COVID-19, some were not satisfied. The level of satisfaction is assumed to be from the fact that the employees feeling safer working from home abiding by the social distancing norms. After performing a regression analysis, it was found that the shift in work and working environment. Further, the financial performance and satisfaction over the changes had less correlation between the departments the respondents work and the preference of working from home or at the office had a moderate positive correlation with the departments.

\section{Conclusion}

Overall, COVID-19 has negatively impacted the profits and NIM of Bank Dhofar and the Bank is fully aware of this and is aiming to rectify the situation. The reason for the negative impact was either the business opportunities halted or stopped completely. The decrease in profit was the provisions made as a precautionary action against the pandemic and the investment in a digitized platform and opening new technologically advanced branches. The operating income was stable confirmed that despite COVID-19 and its limitations, clients were still using Bank Dhofar products and services. The decrease in several branches might be due to the introduction of technologically advanced branches.

\section{Suggestions}

One of the major steps many firms have taken is shifting and investing in a digital platform to perform a business transaction. Bank Dhofar had started doing the same in 2019 but could invest more to remove the aversion amongst the employees. It would appear like affecting the profits and the costs negatively but in the future, it would make up for these losses. This is similar to the recommendation made by U1 Haq and Awan (2020) on branchless banks. Transactions may increase, the number of branches could as the transactions, 
inquiries, and activities would be held online. Such activities and operations would not suffer since there will be a proper infrastructure by then.

\section{References}

1. Abdulai, R.T. \& Baffour Awuah, K.G. (2021). COVID-19 and Sustainability. Sustainable Real Estate in the Developing World, 207-229. http://doi.org/10.1108/978-1-83867-837-120211012

2. Aduhene, D.T. \& Osei-Assibey, E. (2021). Socio-economic impact of COVID-19 on Ghana's Economy: Challenges and Prospects. International Journal of Social Economics, 48 (4), 543-556. http://doi.org/10.1108/IJSE-08-2020-0582

3. Albitar, K., Gerged, A.M., Kikhia, H. \& Hussainey, K. (2021). Auditing in Times of Social Distancing: The Effect of COVID-19 on Auditing Quality. International Journal of Accounting \& Information Management, 29 (1), 169-178. http://doi.org/10.1108/IJAIM-08-2020-0128

4. Alharthi, M., Hanif, I., Ur Rehman, H. and Alamoudi, H. (2021). Satisfaction of Pakistan's Islamic banking system during the COVID-19pandemic Logistic model-based identification of the determinants to improve customer. Journal of Islamic Marketing, Vol. ahead-of-print No. ahead-of-print. http://doi.org/10.1108/JIMA-06-2020-0189

5. Al-Najjar, H., Al-Rousan, N., Al-Najjar, D., Assous, H.F. \& Al-Najjar, D. (2021). Impact of COVID-19 Pandemic Virus on G8 Countries' Financial Indices Based on Artificial Neural Network. Journal of Chinese Economic and Foreign Trade Studies, 14 (1), 89-103. http://doi.org/10.1108/JCEFTS-06-2020-0025

6. Anderson, J. (2010). M-Banking in Developing Markets: Competitive and Regulatory Implications. Info, 12 (1), 18-25. http://doi.org/10.1108/14636691011015358

7. Anh, D.L.T. \& Gan, C. (2020). The Impact of The COVID-19 Lockdown on Stock Market Performance: Evidence from Vietnam. Journal of Economic Studies, 48(4), 836-851. http://doi.org/10.1108/JES-06-20200312

8. Ball, I. (2020). Reflections on Public Financial Management in the COVID-19 Pandemic. Journal of Accounting \& Organizational Change, 16 (4), 655-662. http://doi.org/10.1108/JAOC-10-2020-0160

9. Bank Dhofar (2021). The Best Bank in the Gulf. About Us. https://www.bankdhofar.com/enGB/AboutUs.aspx

10. Banna, H. \& Alam, M.R. (2021). Impact of Digital Financial Inclusion on ASEAN Banking Stability: Implications for the Post-COVID-19 Era. Studies in Economics and Finance, 38(2), 504-523. http://doi.org/10.1108/SEF-09-2020-0388

11. Beck, T., Miles, D. \& Wilson, J. (2020, $13^{\text {th }}$ Aug. 2020). How is Coronavirus Affecting the Banking Sector? Economics Observatory, https://www.economicsobservatory.com/how-coronavirus-affectingbanking-sector

12. Čadil, J., Beránek, M. and Kovář, V. (2021). Likely Winners and Losers in Upcoming COVID-19 Economic Crisis - Lessons Learned from the GFC. Journal of Entrepreneurship in Emerging Economies, Vol. ahead-of-print No. ahead-of-print. https://doi.org/10.1108/JEEE-10-2020-0374

13. Chriscaden, K. (2020). Impact of COVID-19 On People's Livelihoods, Their Health and Our Food Systems. World Health Organization News, https://www.who.int/news/item/13-10-2020-impact-of-COVID19-on-people's-livelihoods-their-health-and-our-food-

systems\#: :text=The\%20economic $\% 20$ and $\% 20$ social $\% 20$ disruption, the $\% 20$ end $\% 20$ of $\% 20$ the $\% 20$ year.

14. Flögel, F. \& Gärtner, S (2020). The COVID-19 Pandemic and Relationship Banking in Germany: Will Regional Banks Cushion an Economic Decline or is A Banking Crisis Looming? Royal Dutch Geographical Society (Koninklijk Nederlands Aardrijkskundig), 111 (3), 416-433. http://doi.org/10.1111/tesg.12440

15. Ghosh, R. and Saima, F.N. (2021). Resilience of Commercial Banks of Bangladesh to the Shocks Caused by COVID-19 Pandemic: An Application of MCDM-Based Approaches. Asian Journal of Accounting Research, Vol. ahead-of-print No. ahead-of-print. http://doi.org/10.1108/AJAR-10-2020-0102

16. Golubeva, O. (2021). Firms' Performance during the COVID-19 Outbreak: International Evidence from 13 Countries. Corporate Governance, Vol. ahead-of-print No. ahead-of-print. http://doi.org/10.1108/CG-092020-0405

17. Hway-Boon, O. \& Ming Yu, C. (2003). Success Factors in E-Channels: The Malaysian Banking Scenario. International Journal of Bank Marketing, 21 (6/7), 369-377. http://doi.org/10.1108/02652320310498519

18. Insaidoo, M., Arthur, L., Amoako, S. and Andoh, F.K. (2021). Stock Market Performance and COVID19 Pandemic: Evidence from a Developing Economy. Journal of Chinese Economic and Foreign Trade Studies, 14(1), 60-73. http://doi.org/10.1108/JCEFTS-08-2020-0055 
19. Jose, J., Mishra, P. \& Pathak, R. (2021). Fiscal and Monetary Response to the COVID-19 Pandemic in India. Journal of Public Budgeting, Accounting \& Financial Management, 33(1), 56-68. http://doi.org/10.1108/JPBAFM-07-2020-0119

20. Karaömer, Y. and Kakilli Acaravc1, S. (2021). The Impact of COVID-19 Outbreak on Borsa Istanbul: An Event Study Method. Journal of Economic and Administrative Sciences, Vol. ahead-of-print No. aheadof-print. http://doi.org/10.1108/JEAS-06-2020-0111

21. Khan, F. K. \& Al Maktoumi, I. S. (2021). Performance Evaluation of Commercial Banks in Oman Using Ratio Analyses. International Journal of Research in Entrepreneurship \& Business Studies, 2 (1), 10-21. http://doi.org/10.47259/ijrebs.212

22. Mansour, H. (2021). How Successful Countries Are in Promoting Digital Transactions during COVID19. Journal of Economic Studies, Vol. ahead-of-print No. ahead-of-print. http://doi.org/10.1108/JES-102020-0489

23. Mukherjea, A. (2010). The Social Politics of Pandemic Influenzas: The Question of (Permeable) International, Inter-Species, and Interpersonal Boundaries. Understanding Emerging Epidemics: Social and Political Approaches, 11, 125-141. https//doi.org/10.1108/S1057-6290(2010)0000011011

24. Mustapa, A.N. and Mohamad, A. (2021). Malaysian Government Business Support and Assistance for Small and Medium Enterprises: A Case of COVID-19 Pandemic Crisis. Sergi, B.S. and Jaaffar, A.R. (Ed.) Modeling Economic Growth in Contemporary Malaysia (Entrepreneurship and Global Economic Growth), 291-305. http://doi.org/10.1108/978-1-80043-806-420211022

25. Ofori, K.S., Boateng, H., Okoe, A.F. \& Gvozdanovic, I. (2017). Examining Customers' Continuance Intentions Towards Internet Banking Usage. Marketing Intelligence \& Planning, 35(6), 756-773. http://doi.org/10.1108/MIP-11-2016-0214

26. Oğuz, M. (2021). The Importance of thorough Financial Reporting During COVID-19 Pandemic: Empirical Evidence from Borsa Istanbul. Grima, S., Özen, E. and Boz, H. (Ed.) Contemporary Issues in Social Science (Contemporary Studies in Economic and Financial Analysis, Vol. 106), Emerald Publishing Limited, Bingley, pp. 239-250. http://doi.org/10.1108/S1569-375920210000106015

27. Oruh, E.S., Mordi, C., Dibia, C.H. \& Ajonbadi, H.A. (2021). Exploring Compassionate Managerial Leadership Style in Reducing Employee Stress Level during COVID-19 Crisis: The Case of Nigeria. Employee Relations, Vol. ahead-of-print No. ahead-of-print. http://doi.org/10.1108/ER-06-2020-0302

28. Ozili, P.K. (2020). COVID-19 Pandemic and Economic Crisis: The Nigerian Experience And Structural Causes. Journal of Economic and Administrative Sciences, Vol. ahead-of-print No. ahead-of-print. http://doi.org /10.1108/JEAS-05-2020-0074

29. Pooya, A., Khorasani, M. A. and Ghouzhdi, S. G. (2020). Investigating The Effect of Perceived Quality of Self-Service Banking on Customer Satisfaction. International Journal of Islamic and Middle Eastern Finance and Management, 13(2), 263-280. http://doi.org/10.1108/IMEFM-12-2018-0440

30. Porterfield, T. (2017, May 18). Regression Analysis. YouTube, https://www.youtube.com/watch?v=0lpfmFnlDHI

31. Priya, R., Gandhi, A.V. \& Shaikh, A. (2018). Mobile banking adoption in an emerging economy: An empirical analysis of young Indian consumers. Benchmarking: An International Journal, 25(2), 743-762. http://doi.org/10.1108/BIJ-01-2016-0009

32. Rehman, M. S. U., Shafiq, M.T. and Afzal, M. (2021). Impact of COVID-19 on Project Performance in the UAE Construction Industry. Journal of Engineering, Design, and Technology, Vol. ahead-of-print No. ahead-of-print. http://doi.org/10.1108/JEDT-12-2020-048

33. Ross, S. (2019, $3^{\text {rd }}$ Jul. 2019). What Net Interest is Typical for a Bank? Investopedia, Dotdash, https://www.investopedia.com/ask/answers/061715/what-net-interest-margin-typical-bank.asp

34. Singh, J. \& Bodla, B. S. (2020). COVID-19pandemic and Lockdown Impact on India's Banking Sector: A Systemic Literature Review. COVID-19 pandemic: A Global Challenge, 21-32.

35. Souiden, N., Ladhari, R. \& Chaouali, W. (2021). Mobile banking adoption: a systematic review. International Journal of Bank Marketing, 39 (2), 214-241. http://doi.org/10.1108/IJBM-04-2020-0182 36. Sreelakshmi, C.C. \& Prathap, S.K. (2020). Continuance Adoption of Mobile-Based Payments in COVID-19 Context: An Integrated Framework of Health Belief Model and Expectation Confirmation Model. International Journal of Pervasive Computing and Communications, 16 (4), 351-369. http://doi.org/10.1108/IJPCC-06-2020-0069

37. Talbot, D. \& Ordonez-Ponce, E. (2020). Canadian Banks' Responses to COVID-19: A Strategic Positioning Analysis. Journal of Sustainable Finance \& Investment, 0:0, 1-8. https://doi.org/10.1080/20430795.2020.1771982

38. Thaker, H. M. T., Thaker, M.A. M. T., Khaliq, A., Pitchay, A. A. \& Hussain, H. I. (2021). Behavioral Intention and Adoption of Internet Banking among Clients' of Islamic Banks in Malaysia: an analysis using 
UTAUT2, Journal of Islamic Marketing, Vol. ahead-of-print No. ahead-of-print. http://doi.org/10.1108/JIMA-11-2019-0228

39. Times of Oman (2021, $7^{\text {th }}$ Jun. 2021). GCC Banks Slash Cash Dividends Highlighting COVID-19 Impact. Times of Oman, https://timesofoman.com/article/102328-gcc-banks-slash-cash-dividendshighlighting-covid-19-impact

40. Tsindeliani, I. A., Proshunin, M. M., Sadovskaya, T. D., Popkova, Z. G., Davydova, M. A. and Babayan, O. A. (2021). Digital Transformation of the Banking System in the Context of Sustainable Development. Journal of Money Laundering Control, Vol. ahead-of-print No. ahead-of-print. http://doi.org/10.1108/JMLC02-2021-0011

41. Ul Haq, I. \& Awan, T.M. (2020). Impact of E-Banking Service Quality on E-Loyalty in Pandemic Times through Interplay of E-Satisfaction. Vilakshan - XIMB Journal of Management, 17(1/2), 39-55. http://doi.org/10.1108/XJM-07-2020-0039

42. WHO (2020). Coronavirus 2019: Questions and Answers

https://www.who.int/emergencies/diseases/novel-coronavirus-2019/question-and-answers-hub/q-adetail/coronavirus-disease-COVID-19 